\title{
Information literacy development in a small country: a practical proposition?
}

\author{
John Crawford
}

\begin{abstract}
This article reviews aspects of information literacy activity in Scotland focusing on policy development and the extent to which this has been successful. It reviews briefly the work of the Scottish Information Literacy Project (2004-2010) and describes the activity of its successor body, The Right Information: Information Skills for a 21 st Century Scotland (2012-to date). A literature review is included to inform performance criteria which can be used to assess the success of the work. The strategy of using Scottish Government and information professional policy documents to inform information literacy policy making is described. Engagement with other professions with an interest in information literacy is found to be essential and the problems identified in engaging with Scottish Government ministers and civil servants are discussed.
\end{abstract}

Although the Right Information has engaged successfully with the information and other professions in Scotland, resourcing and the Scottish Government's emphasis on digital literacy at the expense of information literacy has proved to be a problem.

\section{Background to recent and current developments}

This article reviews the development of information literacy activity in Scotland both in practical and policy terms since the beginning of the century, with an emphasis on post-2012 activity. The Scottish Information Literacy Project, the first of its kind in the British Isles, began in October 2004 and concluded in 2010. It was originally titled: Information literacy, the link between further and higher education as its original aim was to review how information literacy skills, learned in school, could be transferred and further developed in the tertiary sector. This limited objective did not last long and the work of the project soon expanded to include primary education, the workplace and information literacy skills

\section{Author}

John Crawford is an independent libraries professional and founder chair of Information Skills for a $21^{\text {st }}$ Century Scotland.

Email: johncrawford705@yahoo.co.uk

Received 30 July 2016

Accepted 07 November 2016 
development via public libraries. Its principal product was the National Information Literacy Framework Scotland, which attributed information literacy skill levels to successive educational levels from primary school to $\mathrm{PhD}$ level (Irving, 2011). The work of the Project helped to inspire activity in other parts of the British Isles, notably in Wales where the Welsh Information Literacy Project began in late 2009 as a result of a conference held in late November of that year at which I, as director of the Scottish Information Literacy Project, was a principal speaker. The Project functioned in three phases from the end of 2009 and concluded with a conference in Wrexham in March 2015. Its achievements included a framework derived from the Scottish model and the development of accredited information literacy learning (Agored) units (Eynon, 2013). At the concluding conference in March 2015 there were a series of excellent presentations in which the presenters reported on how the Agored units had been used to develop skills among both young and older people and community groups (Chartered Institute of Library and Information Professionals Information Literacy Group, 2015). In Ireland 'The BILI: Building Information Literacy in Ireland' drew on the work of the Scottish Information Literacy Project. Its recommendations centred on a two-tiered approach to IL development: a practitioner-led community of practice that facilitates communication and collaboration, and a high-level advocacy committee to foster a holistic national strategy (Connolly et al., 2012).

The Scottish Information Literacy Project was effectively the foundation of crosssectoral, national information literacy activity in Scotland although there were other activities early in the century. In the early 21 st century the Chartered Institute of Library and Information Professionals in Scotland (CILIPS) produced an information literacy toolkit (Chartered Institute of Library and Information Professionals in Scotland, 2011) which was divided into three sections:

- a practical toolkit to assist in planning the development and implementation of courses;

- a resource bank providing valuable advocacy materials and examples of good practice;

- a CPD area highlighting areas of professional relevance and links to the Chartered Institute of Library and Information Professionals (CILIP) Framework of Qualifications.

It is unclear how influential this product was. Another more enduring initiative is the document How good is our public library service? A Public Library Improvement Model for Scotland originally published in 2007 and now updated (Scottish Library and Information Council, 2015a). This includes a section on information literacy:

[Public] Libraries should offer support for information literacy and digital literacy to improve access and use of information services. Citizens need to develop skills to access information and participate in lifelong learning, in order 
to increase their economic effectiveness and to become active citizens. Libraries, with their knowledgeable workforce, are very well placed to intervene and support people to improve their digital literacy skills.

(Scottish Library and Information Council, 2015a, 14)

The emphasis on the economy and active citizenship is notable and will be returned to later.

During the time of its existence the project attracted collaborators, partners and supporters who felt that the work of the project should continue, and following discussions with key activists this led to the formation in 2012 of The Right Information: Information Skills for a 21 st Century Scotland, an online Community of Practice (Scottish Library and Information Council, 2016; Scottish Information Literacy Project, 2013). The launch took place at the CILIPS annual conference in Dundee in June 2012 and support from CILIPS and the Scottish Library and Information Council (SLIC) has been a conspicuous feature of the Group's activities, including the design of the website by SLIC staff. It brings together a diverse range of information professionals and also representatives from other professions in Scotland to exchange information about information literacy activities, promote innovation and, more recently, to promote information literacy as a national policy issue in Scotland. Communication is by blogging, email and Twitter with face to face meetings twice a year. Activities include presentations, blogging, writing articles and the production of training packages.

Members have produced online learning materials for HE, FE and the primary school sectors. Examples include Project Blaster (NLS, 2013), an online learning package aimed at older primary school pupils which aims to be a fun way to introduce children to information literacy skills. Also notable is Dundee College's Literacy Information Skills project, an employability and information literacy skills training programme (Mawhirt. 2013). The Literacy Information Skills project ran for 12 weeks per group, so up to three classes could attend in any academic year. The core topics of the course covered:

- How the internet works and online safety / privacy;

- Using Google Earth / Maps and learning about directions and using a map;

- Healthy eating and exercise;

- Weighing and measuring (including weighing ingredients and measuring height);

- Completing a library induction and making a comic strip version of the library user guide;

- Visiting Waterstone's to choose books for their own library collection. 
Mawhirt concludes that "outcomes of the project have included both improved literacy skills and improved confidence and social skills." $(2013,23)$.

An example from higher education is SMILE which is "an information and digital literacy training package which aims to teach ... basic skills" to Glasgow Caledonian University students (Glasgow Caledonian University, 2010a). It also contains help on communication and other academic skills in bite-sized sections. Although tailored to the needs of Caledonian University students much of the content is applicable elsewhere. It is comprehensive and includes such topics as communication, evaluation, plagiarism and referencing, research, searching and writing and numeracy.. In order to ensure that the training package addresses the skills most relevant to graduates, its content has been created with direct reference to the National Information Literacy Framework Scotland, and lists of graduate attributes identified by Glasgow Caledonian University and the Confederation of British Industry (Glasgow Caledonian University, 2010b).

More recent and ongoing work includes Lauren Smith's extensive work on the use of information by young people in Scotland (Smith, 2013 \& 2014) and Bill Johnston's work on the use of information by older people (see accompanying article) to support active lifestyles and support their continuing good health.

\section{Literature review}

Demonstrating holistic information literacy strategies within one country presents some problems because the literature essentially consists of some overview studies and policy documents issued by the Scottish Government and professional bodies. In 2011 the veteran information literacy advocate, Woody Horton, published a useful article 'Information Literacy Advocacy - Woody's ten commandments' in which he listed ten lessons which he had learned in information literacy advocacy. These are:

- $\quad$ Patience and perseverance;

- Find an in-house champion;

- $\quad$ Aim for the top;

- Link information literacy to specific long-standing goals and reforms;

- Link to the twenty first century and the global information/knowledge society;

- Resistance to change is "normal";

- Don't bite off more than you can chew;

- $\quad$ Pilot test, experiment and compartmentalize;

- Advocacy is not for the faint of heart; 
- Do your homework.

(Horton, 2011)

These points will be returned to later. Basili (2011) and Whitworth (2011) have reviewed information literacy policy documents from which the following conclusions can be drawn:

1. Information literacy policy documents should be about information literacy and not something else;

2. They should have some form of government endorsement and support;

3. They should be genuinely cross-sectoral covering all education levels from early years to $\mathrm{PhD}$ level, the workplace, health, lifelong learning, employability and skills development and citizenship and civil rights;

4. They should be at least informed and preferably led by the professional bodies of the countries concerned;

5. They should be collaborative with input from all organisations in the countries concerned such as skills development bodies, employers' organizations, trades unions, teaching and learning organizations and relevant NGOs.

Again there is something of a template against which performance can be measured. Although a role for information literacy in the democratic process and civic engagement was identified in the Alexandria Proclamation (Garner, 2005) it has not produced much activity and international comparisons are difficult. Some pioneering work has been done in comparing information literacy strategies (Basili, 2011; Whitworth, 2011) above but what actually happens in practical terms is another matter.

\section{Methodology}

This paper is based on a review of information literacy policy in Scotland since 2004, with a focus on the most recent developments. This included gathering and evaluating relevant policy documents, as well as drawing on my own experience with groups and organisations involved in information literacy strategic planning and delivery within Scotland.

Three case studies were identified as providing particularly important and revealing perspectives on information literacy related questions in Scotland:

- Case Study 1: Young Scot and the 5Rights framework (2015 - present), focusing on implementing and promoting within Scotland the 5Rights framework of rights for children and young people in the digital space; 
- $\quad$ Case Study 2: the SLIC-sponsored one-day conference (February 2015), showcasing developments in information literacy policy and practice across a range of sectors in Scotland, including local and national government, healthcare and housing;

- Case Study 3: the development of the Royal Society of Edinburgh's Spreading the Benefits of Digital Participation enquiry and report (2013-14), describing the role of the SLIC, the Community of Practice, and other key library and information service stakeholders in the development of the final version of this report.

In each case the rationale and motivations for the activity were established, and their effectiveness evaluated. The case studies and conclusions draw extensively on my personal experience and reflections, and it is hoped that these will provide valuable insights for practitioners, policymakers and researchers, particularly into the breadth and range of information literacy engagement in Scotland over recent years, and its successes and challenges.

\section{Relevant policy documents}

In policy-making for information literacy it is necessary to work within the context of relevant policy documents produced by the Scottish Government and other bodies. The Scottish Government's current policy document is A stronger Scotland: the Government's programme for Scotland, 2015-16 (Scottish Government, 2015a) which contains the following 'hooks' on which information literacy might be hung:

- "Increasing our support for those individuals most at risk of digital exclusion" (Scottish Government, 2015a, 30);

- "providing automatic library membership for babies and young children in all 32 local authority areas" (Scottish Government, 2015a, 48);

- "We are committed to improving the health of Scotland's people" (Scottish Government, 2015a, 64);

- "Scotland is leading the way in the UK in involving young people in the democratic process" (Scottish Government, 2015a, 74);

- "Implementing the recommendation in the Libraries Strategy that all libraries should be Wi-Fi enabled" (Scottish Government, 2015a, 79).

The first bullet point necessarily involves the digital participation agenda which is discussed below, while the third bullet point offers an opportunity to pursue the health literacy agenda. The fourth bullet point suggests that the information literacy agenda for young people should be sympathetically received.

There are also documents from the LIS sector. In 2015 SLIC and the Carnegie Trust published Ambition \& Opportunity: A Strategy for Public Libraries in 
Scotland 2015-2020 (Scottish Library and Information Council, 2015b), a strategy for public library development in six key areas which include digital inclusion and economic and social wellbeing. A key statement is:

Libraries support civic engagement by providing access to information supporting participation in a democratic society, and information about consumer rights and citizens' entitlements and responsibilities. Libraries strengthen public life by encouraging and supporting awareness and participation in local decisionmaking and wider civic and political engagement. They contribute to social justice in ensuring equal access to information about service delivery by local and national government. Libraries provide access to the information, ideas and knowledge needed to inform civic participation.

(Scottish Library and Information Council, 2015b, 27)

The economic role of libraries and their role in political and civic engagement is emphasised.

The National Library of Scotland in its Library strategy 2015-2020 emphasises economic and employability issues:

We realise our full economic potential with more and better employment opportunities for our people.

- By supporting the knowledge economy, we contribute to a modern, successful Scotland.

- We seek to build on the current services we provide for Scottish business.

- By supporting learners of all ages, we help them develop in positive, productive ways.

- We provide work experience and volunteer opportunities.

(National Library of Scotland, 2015, 10)

In early 2016, CILIP produced its strategic plan CILIP Action Plan 2016-2020 (2016a). This was accompanied by an evaluation study and Summative Report which usefully summarises the survey data collected to inform the Action Plan (CILIP, 2016b). The Summative Report represents a helpful review of the views of respondents to the questionnaire issued in 2015. It shows, inter alia, that the two highest priorities for respondents are:

- $\quad$ Stand up for Public Libraries (27\%);

- $\quad$ Promote Information Literacy (27\%). 


\section{Case study one: A partner example}

The Right Information: Information Skills for a $21^{\text {st }}$ Century Scotland Community of Practice always seeks to work with appropriate partners and a notable one is Young Scot. Young Scot is the only organisation of its type in the British Isles and reflects the importance attached to the wise use of information by young people in Scotland.

While it is recognised that the internet and digital technologies represent incredible potential and opportunities to young people, Young Scot is also very aware of the risks and challenges that are attached to our digital world. While our young people are supported and protected by a clear set of rights in the analogue world (United Nations Convention on the Rights of the Child - UNCRC), (UNICEF 2016) their rights in the digital space are not yet defined and fully realised by all. 5Rights is a framework that reflects, in a digital context, the rights and support already promised and provided to children and young people in the analogue world.

In April 2015, Young Scot was announced as the lead strategic partner in Scotland for 5Rights. Young Scot would like to see the five 5Rights principles embedded into the DNA of our digital world, and young people made the top priority in the design, provision, and consumption of technology.

The 5Rights framework consists of five clear and simple rights:

1. "The Right to REMOVE

Every child and young person should have the right to easily edit or delete all content they have created" (5Rights, 2016).

2. "The Right to KNOW

Children and young people have the right to know who is holding or profiting from their information, what their information is being used for and whether it is being copied, sold or traded" (5Rights, 2016).

3. "The Right to SAFETY AND SUPPORT

Children and young people should be confident that they "will be protected from illegal practices and supported if confronted by troubling or upsetting scenarios" online (5Rights, 2016).

4. "The Right to INFORMED AND CONSCIOUS CHOICES" (Young Scot, 2016)

"Children and young people should be empowered to reach into creative places online, but at the same time have the capacity and support to easily disengage." (5Rights, 2016). 


\section{5. "The Right to DIGITAL LITERACY}

To access the knowledge that the Internet can deliver, children and young people need to be taught the skills to use, create and critique digital technologies" (5Rights, 2016) and given the tools to negotiate changing social norms.

These principles have been set out for all: government, corporations, educators, parents, and young people - to make sure that young people are the top priority in the design, provision, and consumption of digital content and technologies.

\subsection{Rights Youth Commission}

To ensure that young people remain at the centre of the coalition, and that Young Scot's work is consistent with their views and experiences, Young Scot, the Scottish Government, and 5Rights have recently launched the 5Rights Youth Commission Scotland. Their stated goal is as follows:

... to support a diverse national group of young people to develop informed insights, ideas, recommendations and solutions in relation to how Scotland can become a nation which realises children and young people's digital rights

(MacDonald, 2015)

Nineteen young people, aged 14-21 of diverse backgrounds, have been selected from all across Scotland to take part in this commission. After being launched officially on $23^{\text {rd }}$ February 2016 by Aileen Campbell MSP, Minister of Children and Young People, Youth Commissioners are engaged in a year-long investigation with the goal of producing a piece of work that will be beneficial to public bodies, education, and industries alike.

\subsection{Rights Coalition}

5Rights represents a coalition of organisations and individuals who, collectively, are committed to create a digital world that young people can access "creatively, knowledgeably, and fearlessly" (5Rights, 2016). As the lead strategic partner in Scotland for 5Rights, Young Scot is fully committed in raising awareness of the five 5Rights principles and in growing the 5Rights coalition within Scotland. Key organisations and individuals including Scotland's First Minister on behalf of the Scottish Government, Children \& Young People's Commissioner Scotland, NHS Health Scotland, The Prince's Trust Scotland and Youth Scotland have already signed up to become signatories of the 5Rights coalition - pledging their commitment to make the digital world "a better and more empowering place" for young people in Scotland (Young Scot, 2016).

\subsection{Advocacy and promotion}

Since the founding of the Community of Practice members have been active in a range of activities. These include presentations to fellow professionals ranging from presentations at the annual European Conferences on Information Literacy, 
held in Istanbul (2013), Dubrovnik (2014), Tallinn (2015) and Prague (2016). These have helped to bring the Scottish experience to the attention of a wider world and Scotland's interest in information literacy as a broadly based activity, rather than narrowly focused on higher education. Indeed my invited presentation at the Istanbul conference was praised by Paul Zurkowsi, who coined the term "information literacy", for its breadth of vision. Other presentations have covered the younger and older person's agenda. Presentations at international and national levels have included presentations at LILAC conferences at Limerick and Glasgow and the CILIP conferences in Liverpool (2015) and Brighton (2016). Presentations have also been given to professional groups in Scotland.

The Scottish Parliament maintains several cross-party groups which meet regularly and many of the members are from various professional sectors rather than members of the Scottish Parliament. One of these is the Cross-Party Group on Digital Participation and although to a large extent initially concerned with infrastructural issues it has become more interested in usage issues including information issues and a presentation has been given to the Group by two Community of Practice members.

\section{Case study two: SLIC sponsored one-day conference}

In February 2015 with the full support of SLIC and the support of the Scottish Government a one-day conference was held in Glasgow with the specific aim of taking information literacy beyond the library and information science profession and engaging with other sectors which saw information literacy as relevant to their work. The conference introduction was presented by Colin Cook, Head of Digital Strategies and Programmes, Scottish Government and of the following six presentations only one was from the library and information science sector. Speakers included Hilary Weir from the Scottish Qualifications Agency, who reported on a new qualification, the National Progress Awards which includes information literacy units. Also speaking, Kirsten Urquhart and Hilary Kidd from Young Scot described their Digital Information Strategy which focuses on multiplatform content and how it can be accessed and used.

Blythe Robertson, Policy Head for Health Literacy, Scottish Government and Christine Hoy, Primary Care Development Manager, the Alliance explained that, in 2016, a Health Literacy Place website would be created (NHS Education for Scotland, 2016). Its aims are to:

- $\quad$ [Raise] awareness and the capabilities of information professionals;

- $\quad$ [Promote] the development and spread of existing and new health literacy tools, innovations and technologies;

- Improving access to these... tools and resources;

- [Cater for health literacy needs] at transitions of care.

(Scottish Government, 2014a) 
Christine Hoy noted the need for community resources to be connected and that other people are a prime source of information for most people, something which information professionals all too easily forget. As an example of this she cited Alliance Scotland's ALISS (A Local Information System for Scotland) which is a "search and collaboration tool for health and wellbeing" in Scotland that everyone can contribute to, and that has been "designed by and developed with people with long term conditions and professionals from multiple sectors" (Alliance Scotland, 2016). The site signposts people to useful community support and aims to provide a way for communities to work together to "gather, maintain and share information" (Alliance Scotland, 2016). It essentially lists organisations rather than information (Scottish Recovery Network, 2014).

She was followed by Gregory Colgan, Head of Corporate Debt and Welfare Reform, Dundee City Council. He explained that Dundee City Council has adopted a digital by default strategy in that all Council information is now online. Like other employers, Dundee City Council jobs are now only advertised online, for example. Dundee has pockets of deprivation and has, like other towns, welfare reform challenges, which include:

- Universal Credit;

- Job Searches / Activities;

- Digital Access / Skills;

- $\quad$ Literacy / Numeracy;

- Local access to Services;

- Budgeting;

- Banking;

- In-work benefits.

To tackle these challenges Dundee City Council has set up strategic partnerships within and outwith the council that relate or need to respond to welfare reform. These include Employability and learning and universal credit. Employability and learning includes upskilling individuals and equipping local people with employability skills. Partnership is seen as key and includes the Department of Work and Pensions, libraries and the voluntary sector.

The final speaker was Evelyn McDowall from a housing association, the Wheatley Housing Group. A pilot project, supported by learning centres, provided free broadband to a group of tenants, including Wi-Fi access for 138 families. This was used to support the argument for broadband provision in all social housing. Another priority area was in the development of staff digital skills. 
The day was undoubtedly a strategic success. The scope of information literacy has been extended far beyond its original base in education to activities which would not have been thought of several years ago as having any engagement with information literacy, including housing associations, for example. A wide range of organisations and activities engage with and value information and digital skills and, what is more, are developing policies and plans to improve skills. The planned Scottish Government health literacy strategy is a case in point. The case for information literacy no longer has to be made. The issue is now how policies should be made; implemented and co-ordinated. A plethora of organisations now have some engagement with information and digital skills and it can be difficult to keep track of who is doing what. It is also clear that the digital participation agenda is now dominant in Scottish Government (SG) thinking and information literacy policy making must recognise this. While the need for partnership and collaboration is universally accepted, co-ordination is lacking and there is a need for the Scottish Government to engage with information literacy at a policy level.

After the conference the organisers met to review the day. Ideas resulting from this include:

- A mapping exercise to review overlapping and comparable activities which would benefit from co-ordination;

- Noting conference attendees who could contribute to further activity;

- Drafting a policy statement on information literacy in Scotland aimed at decision makers;

- Preparing a report on information literacy activity in Scotland;

As discussed below some of these ideas are being taken forward, but lack of resources makes comprehensive action difficult (Crawford et al., 2015).

\section{Case study three: Spreading the benefits of digital participation report}

In mid-2013 the Royal Society of Edinburgh (RSE) launched an enquiry entitled Spreading the benefits of digital participation. About ten evidence submissions were sent in from the Library and information sector in Scotland, including the Chartered Institute of Library and Information Professionals in Scotland (CILIPS) and the Scottish Library and Information Council (SLIC). I submitted evidence as then chair of the Community of Practice and there were some seven other evidence submissions from individuals including other members of the Community of Practice. The publication of the interim report in December 2013 implied that all these evidence submissions had been ignored in the report as libraries were only briefly mentioned. There was a high level of consistency in the submissions with much of the evidence focusing on information literacy but this was nowhere mentioned in the report. The report described public libraries as not being a mandatory service (Royal Society of Edinburgh, 2013, 49). 
On the 24 January 2014, Community of Practice representatives met with SLIC staff where it was agreed that both SLIC and the Community of Practice would submit responses to the Royal Society of Edinburgh, expressing disappointment that their evidence had not received appropriate attention and making practical suggestions as to how the final report could be improved.

This was done and SLIC staff also had a positive meeting with representatives of the Committee overseeing the production of the report and RSE staff. The RSE's initial reaction to the Community of Practice's response was conciliatory and assurances were given that the final report would give due weight to the role of libraries in spreading the benefits of digital participation. CILIPS also submitted a response. The final report which appeared in the Spring of 2014 (Royal Society of Edinburgh, 2014) was a huge improvement on the interim report and accurately reflected the evidence submitted by the LIS sector.

The report 'vision' states:

- $\quad$ That everyone in Scotland has the information and digital skills required to participate in the digital arena and prosper from digital opportunities.

- $\quad$ That sustainable online and peer support for continuing learning and development of information and digital skills throughout all stages of life is in place.

- $\quad$ That information and digital skills are embedded across the curriculum and from pre-school to tertiary.'

(Royal Society of Edinburgh, 2014, 43)

The report also recognised the role of public libraries: As a valuable resource in the drive to full digital inclusion, libraries must be supported to maintain and increase their capacity to provide public access to the online world

(Royal Society of Edinburgh, 2014, 37)

Teacher training issues in departments of Scottish education were also identified:

'All Education Faculties within Scottish universities should include components of information literacy, digital skills and computing science in their programmes of study for all primary and secondary teachers.'

(Royal Society of Edinburgh, 2014, 51)

These are valuable advocacy statements but a lack of resources in capitalising on them has proved to be a source of weakness. This has also been the case with the February 2015 conference. 


\section{The challenge of digital inclusion}

This social, economic and to some extent political agenda finds echoes in the Scottish Government's digital inclusion agenda which appears to be both a threat and an opportunity for information literacy. Following the publication of the Spreading the Benefits of Digital Participation report, the Scottish Government decided that the digital inclusion training challenge should be delegated to voluntary organisations with the Scottish Council for Voluntary Organisations (SCVO) in a leading role. This idea was set out in Digital Participation: A National Framework for Local Action (Scottish Government, 2014b). The report stated that:

digital technology cannot be allowed to reinforce social and economic inequalities. Actions will remove barriers to digital participation, tackle inequalities, help people to engage with online public services and provide opportunities to develop skills required for active digital citizens.

(Scottish Government, 2014, Executive Summary)

As a result the Scottish Government is working in partnership with "public, private and third sector organisations to ensure that all sections of Scottish society are able to make confident use of digital technologies and the internet" (Scottish Government, 2016a).' Although Scottish public libraries play an active role in digital skills training, not least because of the movement of benefit payments online, public libraries are only mentioned briefly in the report and no strategic role is allocated to them and only two of the resulting grants, made available by SCVO, have gone to public libraries (Scottish Council for Voluntary Organisations, 2016), with a third application being unsuccessful. Grants are limited to $£ 10,000$ per recipient which is not always sufficient for a public library service. Community of Practice members have met with SCVO staff and for a time there was a Community of Practice SCVO working party but this has produced no substantial outcomes.

There is undoubtedly a digital inclusion issue to address. $22 \%$ of the Scottish population (about 1.3 million people) are not Internet users (Royal Society of Edinburgh, 2013). Meanwhile, the UK Government has developed a UK "digital by default" (UK Government, 2013) strategy whereby all key services are to be delivered online, including social security benefits, and the Scottish Government has introduced a "digital first" strategy (Scottish Government, 2016b) and a devolved training strategy (described above). Furthermore, the need for the promotion of information skills is growing, and this is something which is reflected in the political process. The Scottish Referendum of September 2014 probably stimulated the greatest collective use of information in Scottish history, yet television reporting regularly showed interviews with voters who said they did not have enough information to make a decision. This should not have been the case. The BBC website alone was a comprehensive source of information and yet many people did not know where to find information or how to evaluate it. The conclusion of the Referendum has not ended the process, for both young people 
and adults have continued to be politically engaged after the Referendum. Twothirds of Scottish 16-17 year olds would have been likely to vote in the General election had they had the opportunity, compared with $39 \%$ in the rest of the UK (University of Edinburgh, 2015). The picture for adults is no different. The annual audit of public attitudes to politics, compiled by the Hansard Society, shows that Scots are more politically engaged than the rest of the UK since the Independence Referendum with Scots being far more knowledgeable about and interested in politics than their counterparts south of the border (Settle, 2016)

\section{Policy problems and progress}

Following meetings with Scottish Government civil servants in 2014, who showed a clear understanding of what information literacy is and what it entails, members of the Community of Practice were invited to attend a meeting of the Scottish Government's Digital Scotland Participation Advisory Group which is chaired by the Scottish Government's Cabinet Secretary for Culture, Fiona Hyslop. This provided an opportunity to raise the information literacy agenda with a government minister, which is believed to be the first time that this has happened in the UK. The results of this were mixed. It was clear that although the Scottish Government understands what information literacy is, and views it sympathetically, it is considered to be subsumed within the digital inclusion agenda and is not an independent policy issue. More positively, it was decided to hold a further conference with Scottish Government backing in 2016. It was also decided to set up two Community of Practice working parties, one a joint working party with SCVO and the other to evaluate available learning materials.

Representatives from SCVO and the Carnegie United Kingdom Trust were to be invited to attend Community of Practice meetings. However, no Scottish Government funding was made available.

Over the summer of 2015, I stood down as chair of the Community of Practice, and was replaced by Jenny Foreman. In addition to the two working parties noted, a third on strategy and policy was set up, with myself as Chair. The joint working party with SCVO was not able to achieve much and was abolished in early 2016. The policy and strategy working party has focused on two key areas:

- the development of a research and development agenda;

- the development of an information literacy policy statement aimed at influencing key decision makers in the Scottish Government and civil service.

The research and development agenda is currently being pursued with the Computer and Information Sciences Department at the University of Strathclyde and we are identifying areas of common interest where joint working might be possible. It is also necessary to review the academic level at which different topics might be researched from PG diploma upwards.

An initial information policy statement was drafted and divided into four sections: 
- Democratic and Civil Engagement - informed by Scottish Government policy - Smarter Strategic Objective (Scottish Government, 2015b)

- Education and Lifelong Learning - informed by Scottish Government policy - Smarter Strategic Objective (Scottish Government, 2015b)

- Health and Human Services - informed by Scottish Government policy Healthier Strategic Objective (Scottish Government, 2015c)

- Economic and Social Development - informed by Scottish Government policy - Wealthier and Fairer Strategic Objective (Scottish Government, 2015d)

These four sections are identified from Scottish Government policy documents and relevant documents from the LIS sector (National Library of Scotland, 2015; Scottish Library and Information Council, 2015b). However, after discussion with SLIC it was decided to recast the document as an extension to the Ambition \& Opportunity document which focuses on public libraries (Scottish Library and Information Council, 2015b) with information literacy skills being attributed to each of the six strategic aims in the document:

- Libraries promoting reading, literacy and learning;

- Libraries promoting digital inclusion;

- Libraries promoting economic wellbeing;

- $\quad$ Libraries promoting social wellbeing;

- Libraries promoting culture and creativity;

- Libraries as excellent public services.

(Scottish Library and Information Council, 2015b)

This is being progressed at the time of writing.

\section{Conclusion and evaluation}

Information literacy advocacy in Scotland shows some successes, alongside a frustrating failure to capitalise on some of the progress made. The work of the Scottish Information Literacy Project and the Community of Practice has shown that the focus of information literacy advocacy can be moved away from its traditional base in higher education and towards the role of nationality, political engagement and partnership and collaboration with other professions. The conference of February 2015 made it clear that the importance of information literacy was recognised far beyond the information profession, but the communication and co-ordination issues which this raises have yet to be addressed. 
As in other parts of the United kingdom, and indeed in other parts of the world, the challenge of digital inclusion and its potential to marginalise information literacy is a continuing problem and the only way forward is to continue to make the case and to emphasise that the development of digital skills only increases the need for discriminating information using skills. The more people are made aware of the Internet, the more they need to be trained in its use. It is to be regretted that the information profession in the UK did not promote information literacy to government as a national policy issue before the digital inclusion agenda developed. The CILIP definition of information literacy (CILIP, 2004) was an excellent start but could have benefitted from greater follow-up.

A further issue is the development and co-ordination of research and development activity and this will depend on partnerships between academics, practitioners and activists who can work together to identify common interests and what needs to be done, at what level topics can be tackled, and how they can be funded and the results disseminated and acted upon.

However, the most pressing issue of all is that of resourcing. The Community of Practice does not have the resources to develop and follow up all identified initiative and without a funding stream this will be a continuing problem.

Referring to the work of Horton (2011) and Whitworth (2011), it is possible to undertake some evaluation. The issue of champions has to some extent been addressed by attracting the support of professional bodies and also by engaging with other professions and activities which see the value of information literacy. Aiming for the top has been more problematic. While engaging with civil servants has not been a problem, the meeting with the minister was less successful, with the emphasis on digital literacy rather than information literacy. As indicated in various parts of the article, "linking information literacy to specific long standing goals and reforms" (Horton, 2011) has been key to our activities. While we have done our best to pilot test and experiment, objectively demonstrating the value and impact of our activities is a continuing challenge. We have certainly done our homework and, despite setbacks, have never been "faint hearted" (Horton, 2011). As for some of Whitworth's criteria, we have from the beginning worked crosssectorally both within and beyond the profession and we have worked collaboratively with other relevant organizations. Although professional bodies have been supportive, they have not sought a leadership role. While it might seem obvious that information literacy policies should be about information literacy and not something else, this has in practice proved to be a particularly thorny issue, as separating out digital and information literacy in the minds of policy makers has proved challenging.

The work in Scotland has, to some extent at least, redefined the information literacy agenda. It has shown the need to work at a national level and to understand relevant government policy documents and to recognise how they can be used to further the aims of information literacy. It is necessary to engage with a wide range of partners who are not necessarily linked explicitly to the information profession but have a genuine interest in information literacy and understand its 
value. Information literacy advocacy can be made a national activity in which it is necessary to understand and engage with the political process. Most of all it shows that information literacy advocates have to be ready to play a long game and to realise that quick success is unlikely

\section{References}

5Rights (2016) 5Rights Framework URL http://5rightsframework.com/ [accessed 25.11.16]

Alliance Scotland (2016) A local information system for Scotland (ALISS) URL http://www.alliance-scotland.org.uk/what-we-do/our-work/digital-andtechnology/a-local-information-system-for-scotland-aliss/ [accessed 25.11.16]

Basili, C. (2011) A framework for analysing and comparing Information Literacy policies in European countries, Library Trends, 60(2) 395-418.

Chartered Institute of Library and Information Professionals (2004) Information literacy definition. London: CILIP. URL http://www.cilip.org.uk/cilip/advocacycampaigns-awards/advocacy-campaigns/information-literacy/information-literacy [accessed 25.05.16]

Chartered Institute of Library and Information Professionals (2016a) CILIP Action Plan 2016-2020 URL http://www.cilip.org.uk/sites/default/files/documents/cilip_action_plan_final.pdf [accessed 02.05. 16]

Chartered Institute of Library and Information Professionals (2016b) Action Plan 2016-2020 Consultation - Summative Report URL

http://www.cilip.org.uk/sites/default/files/documents/stf_report_dec2015.pdf p. 16 [accessed 02.05.16]

Chartered Institute of Library and Information Professionals in Scotland (2011) Information Literacy: Securing Change. URL http://www.slainte.org.uk/cilips/infoliteracy/ilindex.htm. [accessed 17.04. 16]

Chartered Institute of Library and Information Professionals Information Literacy Group (2015) Report on Welsh Information Literacy Project closing conference. URL http://www.informationliteracy.org.uk/2015/03/report-on-welshinformation-literacy-project-closing-conference/ [accessed 15.04.16]

Connolly, A. et al. (2012) BILI: Building IL in Ireland. Master of Library and Information Studies, School of Information and Library Studies, University College Dublin.

Crawford, J., Irving C., Smith, L. (2015) Information literacy in Scotland: making it mainstream, CILIP Update, June, 41-43. 
Eynon, A. (2013) Welsh Information Literacy Project, Library and Information Research, 37(114), 17-22.

Garner, S.D. (2005) High-Level Colloquium on Information Literacy and Lifelong Learning. URL http://www.ifla.org/publications/high-level-colloquium-oninformation-literacy-and-lifelong-learning [accessed 25.05.16]

Glasgow Caledonian University (2010a) Welcome to SMILE. URL http://www.gcu.ac.uk/library/SMILE/ [accessed 19.04.16]

Glasgow Caledonian University (2010b) Welcome to the Library. URL https://www.gcu.ac.uk/library/servicesforstaff/informationliteracy/ [accessed 19.04.16]

Horton, F. W. (2011) Information Literacy advocacy-Woody's Ten Commandments, Library Trends, 60(2), 262-276.

Irving, C. (2011) National Information Literacy Framework (Scotland): pioneering work to influence policy making or tinkering at the edges, Library Trends, 60(2), 419-439.

MacDonald, L. (2015) Young Scot, young Scots and iRights URL http://policyhubscotland.co.uk/young-scot-young-scots-and-irights/ [accessed 25.11.16]

Mawhirt, A. (2013) Dundee College's Literacy Information Skills Project, Library and Information Research, 37(114), 23-28

National Library of Scotland (2013) Project Blaster URL http://digital.nls.uk/project-blaster/ [accessed 18.04.16]

National Library of Scotland (2015) The way forward: Library strategy 20152020 URL http://www.nls.uk/media/1190455/2015-strategy.pdf [accessed 02.05.16]

NHS Education for Scotland (2016) The Health Literacy Place. URL: http://www.healthliteracyplace.org.uk/ [accessed 27.11.16].

Royal Society of Edinburgh (2013) Interim report [Spreading the benefits of digital participation] URL https://www.royalsoced.org.uk/1109_Interimreport.html [accessed 25.04.16]

Royal Society of Edinburgh (2014) Spreading the benefits of digital participation URL https://www.royalsoced.org.uk/cms/files/advicepapers/inquiry/digitalparticipation/RSE\%20Digital\%20Report\%20Web\%20Versi on.pdf [accessed 25.04.16]

Settle, M. (2016) "Scots more politically engaged than rest of UK since independence referendum, report says", Herald 14.04.16 URL 
http://www.heraldscotland.com/news/14425238.Scots_more_politically_engaged than_rest_of_UK_since_independence_referendum_report_says/ [accessed 03.06.16]

Scottish Council for Voluntary Organisation (2016) Our Projects URL http://digital.scvo.org.uk/participation/projects/ [accessed 25.05.16].

Scottish Government (2014a) Making it easy. A Health Literacy Plan for Scotland. URL: http://www.gov.scot/Publications/2014/06/9850/5 [accessed 27.11.16]

Scottish Government (2014b) Digital Participation: A National Framework for Local Action URL http://www.gov.scot/Resource/0044/00448804.pdf [accessed 02.05.16]

Scottish Government (2015a) A stronger Scotland: the Government's programme for Scotland, 2015-16 URL http://www.gov.scot/Resource/0048/00484439.pdf [accessed 25.04.16]

Scottish Government (2015b) Smarter strategic objective URL http://www.gov.scot/About/Performance/scotPerforms/objectives/smarter [accessed 21.05.16]

Scottish Government (2015c) Healthier strategic objective URL http://www.gov.scot/About/Performance/scotPerforms/objectives/healthier [accessed 21.05.16]

Scottish Government (2015d) Wealthier and fairer strategic objective URL http://www.gov.scot/About/Performance/scotPerforms/objectives/wealthierAndFa irer [accessed 21.05.16]

Scottish Government (2016a) National Indicator: Use of the Internet URL http://www.gov.scot/About/Performance/scotPerforms/indicator/internet [accessed 25.11.16]

Scottish Government (2016b) Putting people at the heart of Digital Public Services URL: https://blogs.gov.scot/digital/2016/05/12/putting-people-at-theheart-of-digital-public-services/ [accessed 27.11.16].

Scottish Information Literacy Project (2013) The Right Information: Information Skills for a 21st Century Scotland. URL: http://www.therightinformation.org/ [accessed 27.11.16].

Scottish Library and Information Council (2015a) How good is our public library service? A Public Library Improvement Model for Scotland. URL

http://scottishlibraries.org/wpcontent/uploads/2015/05/SLIC_How_Good_Is_Our_Public_Library_WEB.pdf [accessed 18.04.16] 
Scottish Library and Information Council (2015b) Ambition \& Opportunity A Strategy for Public Libraries in Scotland 2015-2020. URL http://scottishlibraries.org/wp-content/uploads/2015/01/Strategy.pdf [accessed 25.04.16]

Scottish Library and Information Council (2016) The Right Information: Information Skills for a $21^{\text {st }}$ Century Scotland URL http://www.therightinformation.org/ [accessed 18.04.16]

Scottish Recovery Network (2014) Find local support with online ALISS tool. URL http://www.scottishrecovery.net/find-local-support-with-aliss-online-tool/ [accessed 02.06.16]

Smith, L. (2014) "Critical Information Literacy for the Development of Political Agency”. IFLA WLIC 2014 Information Literacy Satellite, August 2014.

Smith, L. (2013) Critical information literacy instruction for the development of political agency, Journal of Information Literacy, 7(2) 15-32

UK Government (2013) Government Digital Strategy: December 2013. URL: https://www.gov.uk/government/publications/government-digitalstrategy/government-digital-strategy [accessed 27.11.16].

UNICEF (2016) United Nations Convention on the Rights of the Child URL http://www.unicef.org.uk/UNICEFs-Work/UN-Convention/ [accessed 20.07.16]

University of Edinburgh (2015) Political discussion crucial in classroom, study suggests. URL http://www.ed.ac.uk/news/2015/politicalissuesintheclassroom [accessed 25.11.16]

Whitworth, A. (2011) Empowerment or instrumental progressivism? Analyzing information literacy policies, Library Trends, 60(2) 312-337.

Young Scot (2016) Scotland's young people stand up for their digital rights. URL http://www.youngscot.net/scotlands-young-people-stand-up-for-their-digitalrights/ [accessed 25.11.16]

\section{Acknowledgement}

Thanks to Young Scot staff for information supplied

\section{Open access and copyright}

Library and Information Research is an open access journal. A freely available copy of this paper may be downloaded from the journal's website:

http://www.lirgjournal.org.uk. 
Copyright and associated moral rights in works published in Library and Information Research are retained by the author(s) but this paper may be used freely, with proper attribution, in educational and other non-commercial settings. 